\title{
Self-Monitoring Microbiological Criteria for the Assessment of Hygienic Procedures During Chicken Slaughtering
}

\section{-Author(s)}

\section{Dias $\mathrm{MR}^{\mathrm{I}}$ \\ Dianin KCS" \\ Bersot LS"}

Nero LA'

Universidade Federal de Viçosa, Departamento de Veterinária, Viçosa, MG, Brazil

" Universidade Federal do Paraná, Departamento de Ciências Veterinárias - Setor Palotina, Palotina, PR, Brazil

\section{nail Address}

Corresponding author e-mail address Luciano dos Santos Bersot

Universidade Federal do Paraná, Departamento de Ciências Veterinárias - Setor

Palotina, 85.950-000, Palotina, PR, Brazil

Tel: $\quad+554432118516$

Email: lucianobersot@ufpr.br

\section{EKeywords}

Chicken; self-monitoring; hygiene; slaughtering; processing.

\section{ABSTRACT}

Self-monitoring procedures are adopted by food industries to ensure the quality and safety of final products, considering hygiene and processing criteria. This study aimed to evaluate contamination in chicken processing, considering the microbiological criteria proposed by self-monitoring systems. Environmental samples from reception, slaughtering and processing were collected from three chicken slaughterhouses (SI1, SI2, SI3), and subjected to microbiological analysis to enumerate hygiene indicators microorganisms: mesophilic aerobes, enterobacteriaceae, coliforms and Escherichia coli. The obtained counts were converted to $\log _{10}$ compared by ANOVA $(p<0.05)$ and self-monitoring microbiological criteria for each slaughterhouse were considered. In reception, the mean counts of hygiene indicator microorganisms in SI3 were significantly higher than mean counts observed in SI1 and SI2 ( $<<0.05)$. During slaughtering, the chilling was enough to decrease the mean counts of all hygiene indicator microorganisms in $\mathrm{SI} 1, \mathrm{SI} 2$ and $\mathrm{SI} 3(\mathrm{p}<0.05)$. Based on self-monitoring criteria, in the first stages of slaughtering the facilities presented higher frequencies of chicken carcasses with counts above their respective reference values. SI02 presented carcasses with higher counts after final washing, resulting in environmental samples with higher counts when compared to $\mathrm{SI} 1$ and $\mathrm{SI} 3(\mathrm{p}<0.05)$. Even considering the high counts observed in the initial steps of chicken processing and slaughtering, the results indicated the efficacy of hygienic procedures in providing chicken carcasses and cuts with low microbiological contamination. Self-monitoring criteria supported these results, and the high levels of microbial contamination during the initial steps of slaughtering require subsequent antimicrobial hygienic procedures.

\section{INTRODUCTION}

Food industries seek an ideal system to control microbiological contamination through processing, in order to assure the quality and safety of their end products. This control is a challenge, mainly for the industries that process animal-origin foods, where microbiological contamination is inherent in such raw products, and is usually presented at high levels (Potter et al., 2012; Stannard, 1997). In such context, a diversity of monitoring tools and systems can be employed by food industries to control contamination through the food chain, and particularly meat processing industries have started to adopt selfmonitoring systems based on the recommendations of the federal inspection service and in compliance with international standards for food safety and quality (Brasil 2005).

Self-monitoring systems can be considered as a set of procedures and recommendations based on a holistic approach of the food industry that will be assessed. The organization of such controlling systems 
demands a full knowledge of the processing steps in the target food facility, in order to create a set list of requirements that must be constantly monitored. This set list contains different items, varying from aspects related to the infrastructure (equipment maintenance, environment area, lighting, air circulation), employees (health control, hygienic procedures, dressing), residues (waste, water, pest control) and food processing (monitoring tools, certification)(Brasil 2005). Specific criteria and requirements are defined for each item, based on the food facility characteristics and on internationally and scientifically accepted reference values.

Microbiological contamination is one aspect considered in the control of the food processing environment, once the enumeration of specific groups indicates the hygienic conditions of production (Capita et al., 2003; Ghafir et al., 2008; Scott et al., 2015). With regards to the self-monitoring approach, microbiological contamination through a food processing step is not only assessed by comparing recorded counts with recognized reference values recommended by food hygiene official organs and commissions; self-monitoring systems also consider the historical record of microbiological contamination in a food processing environment to estimate some reference values, usually calculated as the mean count of a specific hygiene indicator added to its standard deviation. So, a specific reference value is calculated for a specific target hygiene microorganism in a specific facility, allowing proper comparison with subsequent data obtained during the hygiene monitoring of this same food industry. This approach allows the companies to identify fluctuations of the hygienic procedures during slaughtering, based not only on reference values, but on self-monitoring reference values in accordance with proper hygienic goals (Sala et al., 2015; Milios et al., 2014; Potter et al., 2012; Scott et al., 2015; Stannard, 1997).

The present study aimed to assess microbiological contamination through chicken processing, considering reference values calculated based on self-monitoring system approach.

\section{MATERIAL AND METHODS}

Three chicken slaughterhouses were included in the present study and briefly characterized as follows:

- Slaughterhouse 1 (SI1): large facility located in Minas Gerais state, Brazil, with the capacity to process 180,000 chickens per day, automatic evisceration system, adopted self-monitoring program, allowed to export a variety of chicken products; the processing is inspected by the Brazilian Ministry of Agriculture;

- Slaughterhouse 2 (SI2): small facility located in Minas Gerais state, Brazil, with the capacity to process 3,500 to 4,000 chickens per day, manual evisceration system, chilled whole chicken is its main end product available for retail sale in its city; the processing is inspected by the city Agriculture Secretariat;

- Slaughterhouse 3 (SI3): large facility located in Paraná State, Brazil, with the capacity to process 330,000 chickens per day, automatic evisceration system, adopted self-monitoring program, allowed to export a variety of chicken products; the processing is inspected by the Brazilian Ministry of Agriculture.

The facilities were visited five to ten times in a period of twelve months; in each visit, samples from different steps of slaughtering process were collected, covering environments, carcasses, equipment, utensils and end products (Table 1). Carcasses and end

Table 1 - Samples and sampling procedures adopted in three chicken slaughterhouses (SI1, SI2, SI3) located in Minas Gerais and Paraná states, Brazil.

\begin{tabular}{|c|c|c|c|c|c|c|c|c|}
\hline stage & sample & detail & code & $\mathrm{SI} 1$ & $\mathrm{SI} 2$ & $\mathrm{SI3}$ & sampling procedure & unit \\
\hline reception & box & bird cage & - & 17 & 13 & 10 & swabbig1 & $\mathrm{CFU} / \mathrm{cm}^{2}$ \\
\hline \multirow[t]{3}{*}{ slaughtering } & carcass & after de-feathering & C1 & 27 & 24 & 50 & rinsing ${ }^{2}$ & CFU/g \\
\hline & & after evisceration & $C 2$ & 28 & 24 & 50 & rinsing 2 & $\mathrm{CFU} / \mathrm{g}$ \\
\hline & & after chilling & C3 & 25 & 24 & 50 & rinsing ${ }^{2}$ & CFU/g \\
\hline \multirow[t]{3}{*}{ processing } & knife & - & - & 11 & 7 & 9 & swabbig ${ }^{1}$ & $\mathrm{CFU} / \mathrm{cm}^{2}$ \\
\hline & table & cutting boards & - & 11 & 7 & 10 & swabbig ${ }^{1}$ & $\mathrm{CFU} / \mathrm{cm}^{2}$ \\
\hline & hand & employees hands & - & 11 & 7 & 10 & swabbig ${ }^{1}$ & $\mathrm{CFU} / \mathrm{cm}^{2}$ \\
\hline \multirow[t]{3}{*}{ cuts } & leg & - & - & 11 & 2 & 10 & rinsing ${ }^{2}$ & CFU/g \\
\hline & wing & - & - & 12 & 2 & 10 & rinsing ${ }^{2}$ & CFU/g \\
\hline & breast & - & - & 12 & 2 & 10 & rinsing $^{2}$ & CFU/g \\
\hline total & - & - & - & 165 & 112 & 219 & - & - \\
\hline
\end{tabular}

${ }^{1}$ sampling of $400 \mathrm{~cm}^{2} ;{ }^{2}$ sampled according USDA/FSIS, 2014. CFU: colony-forming units 
products were sampled by rinsing, according to USDA/ FSIS (2014): samples were obtained, transferred to sterile bags and weighed; then, $400 \mathrm{~mL}$ of phosphate buffer pH 7.0 (Oxoid Ltd., Basingstoke, England) were added to samples and homogenized. Surface samples were obtained by swabbing sterile sponges previously moistened with $40 \mathrm{~mL}$ of phosphate buffer $\mathrm{pH} 7.0$ (Oxoid) in four $100 \mathrm{~cm}^{2}$ limited areas of the target sample, and then transferred to sterile bags and added to $160 \mathrm{~mL}$ of phosphate buffer pH 7.0 (Oxoid), completing the final volume of $200 \mathrm{~mL}$ per sample. All samples were kept under refrigeration until analysis.

The collected samples were ten-fold diluted in $\mathrm{NaCl}$ $0.85 \%(\mathrm{w} / \mathrm{v})$ and plated for enumeration of hygiene indicator microorganisms using Petrifilm ${ }^{\mathrm{TM}}$ plates (3M Microbiology, St.Paul, MN, USA). Mesophilic aerobes were enumerated using Petrifilm ${ }^{\mathrm{TM}}$ Aerobic Count, after incubation at $35^{\circ} \mathrm{C}$ for $24 \mathrm{~h}$; enterobacteriaceae organisms were enumerated using Petrifilm ${ }^{\text {TM }}$ Enterobacteriaceae, after incubation at $35^{\circ} \mathrm{C}$ for $24 \mathrm{~h}$; coliforms and Escherichia coli were enumerated using Petrifilm ${ }^{\text {TM }}$ Escherichia coli, after incubation at $35^{\circ} \mathrm{C}$ for 24 and 48 h, respectively. After incubation, typical colonies were enumerated for each microbiological group, and the results were expressed as colonyforming units per $\mathrm{g}$ or $\mathrm{cm}^{2}$ (CFU/g or $\mathrm{cm} 2$ ).
The chlorine concentration (parts per million) and temperature $\left({ }^{\circ} \mathrm{C}\right)$ of the water used in the chiller tanks at the end of the chicken slaughtering process were monitored during the visits according to the quality control procedures adopted in the facilities.

Microbiological counts were converted in $\log _{10}$ and compared by Analysis of Variance $(p<0.05)$, in order to check significant differences between facilities and slaughtering stages. In addition, selfmonitoring reference values were calculated for each microbiological group recorded from chicken carcasses during the slaughtering stages in each facility, considering their mean values added to their respective standard deviations; then, the frequencies of those chicken carcasses that presented counts higher than these reference values were calculated and compared by chi-square $(p<0.05)$. All statistical analyses were conducted using the software XLStat Version 2013.5.06 (AddinSoft, New York, NY, USA).

\section{RESULTS AND DISCUSSION}

Table 2 presents the mean counts of hygiene indicator microorganisms recorded in the reception of the three chicken slaughterhouses. SI3 presented higher counts for all microbiological groups when

Table 2 - Mean counts ( \pm standard deviation) of mesophilic aerobes (MA), Enterobacteriaceae (EB), coliforms (TC) and Escherichia coli (EC) in bird cages from three chicken slaughterhouses (SI1, SI2, SI3). Values in log CFU/ $\mathrm{cm}^{2}$.

\begin{tabular}{|c|c|c|c|c|}
\hline Microbial group & $\mathrm{SI} 1$ & $\mathrm{SI} 2$ & $\mathrm{SI} 3$ & ANOVA \\
\hline $\mathrm{MA}$ & $5.88 \pm 0.49^{b}$ & $5.95 \pm 0.61^{b}$ & $8.52 \pm 1.31^{a}$ & $F_{(2,36)}: 38.76, p<0.001$ \\
\hline$E B$ & $4.47 \pm 0.91^{b}$ & $4.75 \pm 0.72^{b}$ & $5.96 \pm 1.03^{a}$ & $\mathrm{~F}_{(2,33)}: 8.88, \mathrm{p}<0.001$ \\
\hline $\mathrm{TC}$ & $4.60 \pm 0.75^{b}$ & $4.58 \pm 0.68^{b}$ & $5.73 \pm 0.71^{a}$ & $\mathrm{~F}_{(2,32)}: 8.91, \mathrm{p}<0.001$ \\
\hline $\mathrm{EC}$ & $4.52 \pm 0.70^{b}$ & $4.34 \pm 0.58^{b}$ & $5.51 \pm 0.57^{a}$ & $F_{(2.30)}: 0.41, p<0.001$ \\
\hline
\end{tabular}

ANOVA: analysis of variance; $p$ : level of significance $(p<005)$. For each microbial group, values followed by different letters in the same line are significantly different.

compared to SI1 and SI2, suggesting poor hygienic conditions in chicken cages and the relevance of the intrinsic contamination in animals as the source of entry of microorganisms into slaughterhouses, as described by Nogrady et al. (2008) and Tirolli \& Costa (2006). However, other aspects of chicken production must be considered to explain such differences and not being considered in this study, such as the age of the birds, their body weights, the feed withdrawal and transport duration and the environment conditions: such aspects can interfere directly the initial microbial contamination of slaughtering facilities.

Mean counts of microbiological groups obtained during chicken slaughtering in $\mathrm{SI}, \mathrm{SI} 2$ and $\mathrm{SI} 3$ are presented in Table 3. Table 4 presents the reference values calculated for each stage of slaughtering, microbiological group and slaughterhouse and Figure 1 presents the frequencies of chicken carcass samples that presented microbiological counts higher than these reference values. Table 5 presents the mean values of chilling tank temperatures and chlorine recorded in SI1, $\mathrm{SI}$, and SI3. By comparing the three slaughterhouses, it can be observed that SI3 presented higher counts in the initial slaughtering stages $(\mathrm{C} 1$, chicken after defeathering) when compared to SI1 and SI2 ( $p<0.05$, Table 3), except for Enterobacteriaceae and E. coli(similar counts to SI1). Recorded counts after evisceration of chicken (C2) varied among slaughterhouses, without a coherent pattern (Table 3), while the microbiological counts in the chicken carcasses after pre-chilling (C3) were higher in SI2 when compared to $\mathrm{SI} 1$ and $\mathrm{SI} 3$ for all researched microbiological groups $(p<0.0 .5$, 
Table 3 - Mean counts ( \pm standard deviation) of mesophilic aerobes (MA), Enterobacteriaceae (EB), coliforms (TC) and Escherichia coli $(\mathrm{EC})$ in different stages of chicken slaughtering process (C1: after de-feathering; C2: after evisceration; C3: after chilling) from three chicken slaughterhouses $(\mathrm{SI} 1, \mathrm{SI}, \mathrm{SI})$. Values in log CFU/g.

\begin{tabular}{|c|c|c|c|c|c|}
\hline Microbial group & stage & $\mathrm{SI} 1$ & $\mathrm{SI} 2$ & $\mathrm{SI} 3$ & ANOVA \\
\hline \multirow[t]{4}{*}{ MA } & C1 & $5.60 \pm 0.61^{\mathrm{aB}}$ & $4.78 \pm 0.32^{\mathrm{ac}}$ & $6.90 \pm 1.53^{\mathrm{aA}}$ & $F_{(2,98)}: 31.24, p<0.001$ \\
\hline & $\mathrm{C} 2$ & $5.48 \pm 0.75^{\mathrm{aAB}}$ & $4.79 \pm 0.34^{\mathrm{aB}}$ & $5.91 \pm 1.94^{\mathrm{bA}}$ & $F_{(2,98)}: 4.84, p=0.010$ \\
\hline & $\mathrm{C3}$ & $1.19 \pm 0.98^{b c}$ & $3.67 \pm 0.32^{\mathrm{bA}}$ & $2.33 \pm 0.41^{C B}$ & $F_{(2,89)}: 100.70, p<0.001$ \\
\hline & ANOVA & $F_{(2,72)}: 231.15, p<0.001$ & $F_{(2,66)}: 86.94, p<0.001$ & $F_{(2,147)}: 138.74, p<0.001$ & \\
\hline \multirow[t]{4}{*}{ EB } & C1 & $4.93 \pm 0.53^{\mathrm{aA}}$ & $4.17 \pm 0.39^{a \mathrm{~B}}$ & $5.51 \pm 1.38^{\mathrm{aA}}$ & $F_{(2,94)}: 13.52, p<0.001$ \\
\hline & $\mathrm{C} 2$ & $4.90 \pm 0.63^{\mathrm{aA}}$ & $4.14 \pm 0.45^{\mathrm{aA}}$ & $4.56 \pm 1.58^{\mathrm{bA}}$ & $F_{(2,94)}: 2.44, p=0.093$ \\
\hline & $\mathrm{C} 3$ & $0.50 \pm 1.19^{b c}$ & $2.89 \pm 0.71^{\mathrm{bA}}$ & $1.22 \pm 0.62^{с B}$ & $F_{(281)}: 54.08, p<0.001$ \\
\hline & ANOVA & $F_{(2,60)}: 169.88, p<0.001$ & $F_{(2,65)}: 42.36, p<0.001$ & $F_{(2,144)}: 158.81, p<0.001$ & \\
\hline \multirow[t]{4}{*}{ TC } & C1 & $4.72 \pm 0.61^{\mathrm{aB}}$ & $3.95 \pm 0.43^{a c}$ & $5.38 \pm 1.28^{\mathrm{aA}}$ & $F_{(2,95)}: 16.44, p<0.001$ \\
\hline & $\mathrm{C} 2$ & $4.71 \pm 0.61^{\mathrm{aA}}$ & $4.02 \pm 0.41^{\mathrm{aB}}$ & $4.55 \pm 1.31^{\mathrm{bAB}}$ & $F_{(2,95)}: 3.15, p=0.047$ \\
\hline & $\mathrm{C} 3$ & $0.34 \pm 1.24^{\mathrm{bB}}$ & $2.54 \pm 0.76^{\mathrm{bA}}$ & $0.91 \pm 0.62^{\mathrm{cB}}$ & $F_{(2,80)}: 46.43, p<0.001$ \\
\hline & ANOVA & $F_{(2,61)}: 148.40, p<0.001$ & $F_{(2,64)}: 50.35, p<0.001$ & $F_{(2,145)}: 224.86, p<0.001$ & \\
\hline \multirow[t]{4}{*}{ EC } & C1 & $4.53 \pm 0.59^{\mathrm{aA}}$ & $3.74 \pm 0.48^{\mathrm{aB}}$ & $5.04 \pm 1.24^{\mathrm{aA}}$ & $F_{(2,95)}: 14.03, p<0.001$ \\
\hline & $\mathrm{C} 2$ & $4.44 \pm 0.64^{\mathrm{aA}}$ & $3.71 \pm 0.28^{\mathrm{aB}}$ & $4.32 \pm 1.17^{\mathrm{bA}}$ & $F_{(2,92):}: 4.44, p=0.014$ \\
\hline & C3 & $0.60 \pm 1.20^{\mathrm{bB}}$ & $2.33 \pm 0.90^{\mathrm{bA}}$ & $0.67 \pm 0.53^{\mathrm{cB}}$ & $F_{(2,76)}: 39.80, p<0.001$ \\
\hline & ANOVA & $F_{(2,60)}: 113.33, p<0.001$ & $F_{(2,61)}: 37.04, p<0.001$ & $F_{(2,142)}: 253.04, p<0.001$ & \\
\hline
\end{tabular}

ANOVA: analysis of variance; $p$ : level of significance $(p<005)$. For each microbial group, values followed by different lowercase letters per row are significantly different, and values followed by different uppercase letters per line are significantly different.

Table 4 - Reference values for self-monitoring microbiological analysis of microbial contamination in chicken carcasses by mesophilic aerobes (MA), Enterobacteriaceae (EB), coliforms (TC) and Escherichia coli (EC) for each chicken slaughterhouse (SI1, SI2, SI3) and chicken slaughtering stage. Values in CFU/g and calculated by mean values added to their respective standard deviations.

\begin{tabular}{lccccc}
\hline Slaughterhouse & Stage & \multicolumn{4}{c}{ Microbial group } \\
\cline { 3 - 6 } & & MA & EB & TC & EC \\
\hline SI1 & C1 & 6.20 & 5.45 & 5.33 & 5.12 \\
& C2 & 6.23 & 5.54 & 5.32 & 5.08 \\
SI2 & C3 & 2.18 & 1.70 & 1.57 & 1.81 \\
& C1 & 5.11 & 4.56 & 4.37 & 4.22 \\
& C2 & 5.13 & 4.59 & 4.43 & 3.99 \\
SI3 & C3 & 3.98 & 3.60 & 3.30 & 3.23 \\
& C1 & 8.43 & 6.89 & 6.66 & 6.28 \\
\hline & C2 & 7.86 & 6.14 & 5.86 & 5.49 \\
\hline
\end{tabular}

Table 3). The higher temperatures in the chilling tanks from SI2 when compared to SI1 and SI3 can explain these results (Table 5), showing that temperature and water renewal were more important as factors of microbiological control than chlorine, which on its own showed no effect, as also observed by Allen et al. (2000), Jimenez et al. (2003), Matias et al. (2010), and Rodrigues et al. (2008). Chilling is considered to play a major role in microbiological contamination during chicken slaughtering, and studies assessing the use of alternative procedures and equipment, such as spraying of cold air instead of immersion in cold water, indicate its relevance in reducing the counts in chicken carcasses (Hutchison et al., 2006; Vaidya et al., 2005; Zweifel et al., 2015). Despite not being considered in the present study, pre-chilling also is important to reduce microbial counts in chicken carcasses, but temperature, water inflow and chlorine concentration must be also monitored for proper effect of this procedure (Cavani et al., 2010).

Table 5-Mean values ( \pm standard deviation) of temperature $\left({ }^{\circ} \mathrm{C}\right)$ and chlorine content $(\mathrm{ppm})$ in water used for chilling of chicken carcasses during slaughtering in three chicken slaughterhouses (SI1, SI2, SI3).

\begin{tabular}{lccc}
\hline Parameter & SI1 & SI2 & SI3 \\
\hline Temperature & $0.93 \pm 0.67$ & $8.00 \pm 1.73$ & $0.63 \pm 0.59$ \\
Chlorine & $3.09 \pm 0.74$ & $1.63 \pm 2.29$ & $0.66 \pm 0.24$ \\
\hline
\end{tabular}

Considering the microbiological contamination of chicken carcasses in the slaughtering stages in each slaughterhouse, a clear pattern can be observed. SI1 and SI2 presented a significant decrease of microbiological counts only after $C 2(p<0.05$, Table 3$)$, while SI3 presented a significant decrease after $\mathrm{C} 1$ and C2 ( $p<0.05$, Table 3). However, with regards to specific microbiological criteria from self-monitoring systems, a different scenario is observed in each slaughterhouse, according to each microbiological group (Figure 1). Even presenting similar counts in chicken carcasses in C1 and C2 (Table 3), SI1 presented an increase of samples with counts higher than reference values 

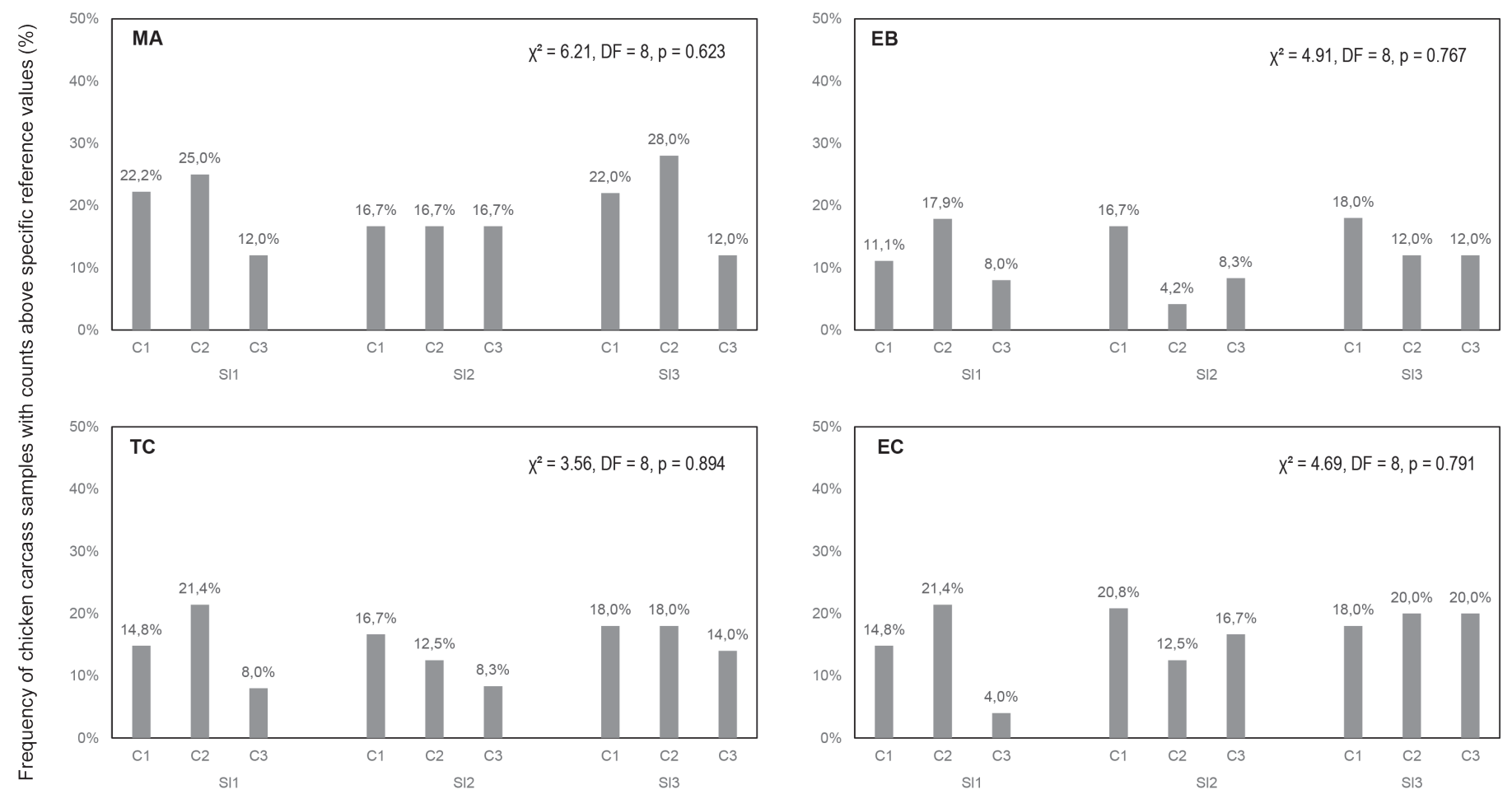

Slaughtering step and Slaughterhouse

Figure 1 - Frequencies of chicken carcasses obtained in three stages of slaughtering (C1: after de-feathering; $\mathrm{C2}$ : after evisceration; $\mathrm{C}$ : after chilling) from three chicken slaughterhouses (SI1, SI2, SI3) presenting hygiene indicator microorganisms (MA: mesophilic aerobes, EB: enterobacteriaceae, TC: coliforms, EC: Escherichia coli) with counts above reference values calculated based on self-control microbiological criteria (mean value added standard deviation). $\chi^{2}$ : chi square; DF: degrees of freedom; $p$ : level of significance). Reference values detailed in Table 4.

among these slaughtering stages (Figure 1). In SI2, an increase can be observed of samples with higher counts than reference values of Enterobacteriaceae and E. coli among C2 and C3 (Figure 1), with significant differences among mean counts even being recorded (Table 3). Finally, SI3 presented an increase of sample frequencies with counts higher than reference values of mesophilic aerobes and E. coli among C1 and C2 (Figure 1), despite their mean counts being significantly different (Table 3). These results demonstrate the relevance of the intermediary stages of slaughtering as potential sources of microbiological contamination, like the automatic evisceration in large slaughterhouses in which the control can be more difficult (Goksoy et al., 2004; Matias et al., 2010; Rodrigues et al., 2008; Vaidya et al., 2005; Zweifel et al., 2015). In addition, based on this analysis it becomes clear that there is a need to consider additional microbiological criteria to assess the hygienic procedures in chicken slaughterhouses. Even presenting low microbiological counts in some key steps of slaughtering, the frequencies of chicken carcass samples with counts higher than reference values indicate an absence of proper control of hygienic procedures, jeopardizing the processing steps of slaughterhouses and indicating the need for corrective measures in the process (Altekruse et al., 2009; Heggum et al., 2015; i Sala et al., 2015; Stannard, 1997).

Table 6 presents the microbiological counts recorded in the samples obtained from the processing environment of SI1, SI2, and SI3. In general, samples obtained in SI2 presented higher microbiological counts when compared to samples obtained in SI1 and $\mathrm{SI}$, except by Enterobacteriaceae and coliforms counts in tables, which presented similar counts to those obtained in SI1 (Table 6).Abu-Ruwaida et al. (1994) described that equipment and utensils used for chicken slaughtering and processing are linked to microbiological contamination of chicken carcasses and end products. In addition, it is well known that contamination through food coming into contact with surfaces in the processing environment occurs due to poor hygienic conditions as a consequence of inadequate and/or inefficient cleaning and disinfection procedures (Reij \& Den Aantrekker 2004).

The mean counts of microbiological groups recorded from chicken cuts obtained in $\mathrm{SI} 1, \mathrm{SI} 2$, and $\mathrm{SI}$ are presented in Table 7. As observed for the samples obtained from the processing environment, higher microbiological counts were observed from samples obtained in SI2 compared to SI1 and SI3. Álvarez- 
Table 6 - Mean counts ( \pm standard deviation) of mesophilic aerobes (MA), Enterobacteriaceae (EB), coliforms (TC) and Escherichia coli (EC) in different samples of processing environment from three chicken slaughterhouses (SI1, SI2, SI3). Values in $\log \mathrm{CFU} / \mathrm{g}$.

\begin{tabular}{|c|c|c|c|c|c|}
\hline Microbial group & Processing environment & $\mathrm{SI} 1$ & $\mathrm{SI} 2$ & $\mathrm{SI} 3$ & ANOVA \\
\hline \multirow[t]{3}{*}{ MA } & Table & $3.18 \pm 0.69^{b}$ & $4.12 \pm 0.87^{a}$ & $2.50 \pm 0.33^{b}$ & $F_{(2,21)}: 12.66, p<0.001$ \\
\hline & Hand & $2.59 \pm 0.75^{b}$ & $4.42 \pm 0.73^{a}$ & $2.25 \pm 0.46^{b}$ & $F_{(2,23)}: 22.61, p<0.001$ \\
\hline & Knife & $2.85 \pm 0.81^{b}$ & $4.52 \pm 0.84^{a}$ & $1.96 \pm 0.53^{b}$ & $F_{(2,20)}: 22.84, p<0.001$ \\
\hline \multirow[t]{3}{*}{ EB } & Table & $2.35 \pm 0.87^{a}$ & $2.95 \pm 1.01^{\mathrm{a}}$ & $1.24 \pm 0.63^{b}$ & $F_{(2,22)}: 9.47, p=0.001$ \\
\hline & Hand & $1.91 \pm 0.61^{b}$ & $3.39 \pm 0.46^{a}$ & $0.10 \pm 0.47^{c}$ & $F_{(2,15)}: 45.34, p<0.001$ \\
\hline & Knife & $1.82 \pm 0.93^{b}$ & $3.28 \pm 1.05^{a}$ & $0.71 \pm 0.73^{c}$ & $F_{(2,21)}: 14.98, p<0.001$ \\
\hline \multirow[t]{3}{*}{ TC } & Table & $2.00 \pm 0.49^{a}$ & $2.30 \pm 0.31^{a}$ & $0.08 \pm 0.37^{b}$ & $F_{(2,18)}: 64.12, p=0.044$ \\
\hline & Hand & $1.24 \pm 0.55^{b}$ & $3.21 \pm 0.57^{a}$ & $1.70 \pm 0.00^{b}$ & $F_{(2,12)}: 21.67, p<0.001$ \\
\hline & Knife & $1.51 \pm 0.57^{b}$ & $3.24 \pm 1.07^{a}$ & $0.09 \pm 0.43^{c}$ & $F_{(2,15)}: 24.54, p<0.001$ \\
\hline \multirow[t]{3}{*}{ EC } & Table & $1.19 \pm 0.50^{b}$ & $2.44 \pm 0.06^{a}$ & $-0.02 \pm 0.25^{c}$ & $F_{(2,8)}: 48.99, p<0.001$ \\
\hline & Hand & $1.41 \pm 0.51^{b}$ & $3.18 \pm 0.51^{\mathrm{a}}$ & $1.70 \pm 0.00^{b}$ & $F_{(2,8)}: 15.56, p<0.001$ \\
\hline & Knife & $1.51 \pm 0.47^{a}$ & $3.11 \pm 1.07^{a}$ & $0.15 \pm 0.30^{b}$ & $F_{(2,9)}: 15.41, p<0.001$ \\
\hline
\end{tabular}

ANOVA: analysis of variance; $p$ : level of significance $(p<005)$. For each microbial group, values followed by different letters per line are significantly different.

Astorga et al. (2002) associated high counts in chicken cuts to inadequate and poor hygienic procedures during chicken slaughtering and processing. The same interpretation can be considered in the present study, based on the previously described data that demonstrated poor hygienic conditions and absence of proper control in SI2 (Tables 3 and 6, Figure 1). These results indicate that the microbiological contamination of end products is simply a reflection of the hygienic conditions during processing. Despite this, all chicken cuts and chicken carcasses obtained at the end of slaughtering (C3) presented results in accordance with current Brazilian standards, which determine a limit of $4 \mathrm{log}$ CFU/g of thermotolerant coliforms in such foods, this being considered suitable for retail sale and consumption (Brasil 2001).
The obtained data indicated the relevance of microbiological groups in assessing the hygienic procedures during chicken slaughtering, and also the need to consider additional criteria for the proper control of processing. Self-monitoring microbiological criteria allowed an alternative interpretation of the adequacy of hygienic procedures and contamination control in the studied slaughterhouses. Based on such information, it was possible to identify the evisceration and chilling stages as being key steps in controlling microbiological contamination during chicken slaughtering in the studied facilities, as well as the water temperature in the chilling immersion tanks. Finally, contamination during chicken slaughtering and processing was considered relevant to the microbiological counts recorded in end products.

Table 7 - Mean counts ( \pm standard deviation) of mesophilic aerobes (MA), Enterobacteriaceae (EB), coliforms (TC) and Escherichia coli (EC) in different samples of chicken cuts obtained from three chicken slaughterhouses (SI1, SI2, SI3). Values in $\log$ CFU/g.

\begin{tabular}{|c|c|c|c|c|c|}
\hline Microbial group & Cut & SI1 & $\mathrm{SI} 2$ & $\mathrm{SI} 3$ & ANOVA \\
\hline \multirow[t]{3}{*}{ MA } & Breast & $2.52 \pm 0.47^{b}$ & $4.72 \pm 0.00^{\mathrm{a}}$ & $2.51 \pm 0.21^{b}$ & $F_{(2,19)}: 17.14, p<0.001$ \\
\hline & Leg & $2.60 \pm 0.56^{b}$ & $4.97 \pm 0.00^{a}$ & $2.26 \pm 0.36^{b}$ & $F_{(2,18)}: 15.01, p=0.000$ \\
\hline & Wing & $2.48 \pm 0.52^{b}$ & $5.07 \pm 0.00^{\mathrm{a}}$ & $2.80 \pm 0.19^{b}$ & $F_{(2,17)}: 21.00, p<0.001$ \\
\hline \multirow[t]{3}{*}{ EB } & Breast & $1.78 \pm 0.49^{b}$ & $3.26 \pm 0.83^{a}$ & $1.64 \pm 0.47^{b}$ & $F_{(2,19)}: 8.77, p=0.002$ \\
\hline & Leg & $1.69 \pm 0.79^{b}$ & $3.82 \pm 0.15^{a}$ & $1.12 \pm 0.58^{b}$ & $F_{(2,19)}: 13.50, p=0.000$ \\
\hline & Wing & $1.61 \pm 0.68^{b}$ & $3.59 \pm 0.56^{a}$ & $1.90 \pm 0.37^{b}$ & $F_{(2,19)}: 10.81, p=0.001$ \\
\hline \multirow[t]{3}{*}{ TC } & Breast & $1.48 \pm 0.53^{b}$ & $3.11 \pm 0.81^{\mathrm{a}}$ & $0.55 \pm 0.36^{c}$ & $F_{(2,20)}: 26.64, p<0.001$ \\
\hline & Leg & $1.41 \pm 0.62^{b}$ & $3.13 \pm 0.64^{a}$ & $0.67 \pm 0.67 c$ & $F_{(2,19)}: 13.01, p=0.000$ \\
\hline & Wing & $1.41 \pm 0.76^{b}$ & $3.15 \pm 0.25^{a}$ & $1.03 \pm 0.33^{b}$ & $F_{(2,19)}: 3.75, p=0.001$ \\
\hline \multirow[t]{3}{*}{ EC } & Breast & $1.086 \pm 0.54^{b}$ & $2.76 \pm 1.04^{\mathrm{a}}$ & $0.23 \pm 0.38^{c}$ & $F_{(2,20)}: 22.18, p<0.001$ \\
\hline & Leg & $1.136 \pm 0.44^{b}$ & $2.83 \pm 0.73^{a}$ & $0.58 \pm 0.56^{b}$ & $F_{(2,17)}: 15.77, p=0.000$ \\
\hline & Wing & $1.325 \pm 0.70^{b}$ & $2.86 \pm 0.97^{a}$ & $0.85 \pm 0.35^{b}$ & $F_{(2,19)}: 10.17, p=0.001$ \\
\hline
\end{tabular}

ANOVA: analysis of variance; $p:$ level of significance $(p<005)$. For each microbial group, values followed by different letters per line are significantly different. 


\section{ACKNOWLEDGEMENTS}

The authors are thankful to Conselho Nacional de Desenvolvimento Científico e Tecnológico (CNPq), Coordenação de Aperfeiçoamento de Pessoal de Nível Superior (CAPES), and Fundação de Amparo à Pesquisa do Estado de Minas Gerais (FAPEMIG).

\section{REFERENCES}

Abu-Ruwaida AS, Sawaya WN, Dashti BH, Murad M, Al-Othman HA. Microbiological quality of broilers during processing in a modern commercial slaughterhouse in Kuwait. Journal of Food Protection 1994;57(10):887-892.

Allen VM, Corry JEL, Burton CH, Whyte RT, Mead GC. Hygiene aspects of modern poultry chilling. International Journal of Food Microbiology 2000;58(1-2):39-48

Altekruse SF, Berrang ME, Marks H, Patel B, Shaw WK, Saini $P$, et al. Enumeration of Escherichia coli cells on chicken carcasses as a potential measure of microbial process control in a random selection of slaughter establishments in the United States. Applied and Environmental Microbiology 2009;75(11):3522-3527.

Álvarez-Astorga M, Capita R, Alonso-Calleja C, Moreno B, Garcı冈aFernández MC. Microbiological quality of retail chicken by-products in Spain. Meat Science 2002;62(1):45-50.

Brasil. Resolução $n^{\circ}$ 12, de 2 de janeiro de 2001. Regulamento técnico sobre os padrões microbiológicos para alimentos. Brasília, DF: Anvisa; 2001. 48 p.

Brasil. Circular no 175/2005/CGPE/DIPOA, de 16 de maio de 2005. Procedimentos de verificação dos programas de autocontrole. Brasília: MAPA; 2005.

Capita R, Alvarez-Astorga M, Alonso-Calleja C, Moreno B, Camino GarciaFernandez $\mathrm{M}$. Occurrence of salmonellae in retail chicken carcasses and their products in Spain. International Journal of Food Microbiology 2003;81(2):169-173

Cavani R, Schocken-Iturrino RP, Garcia TCFL, Oliveira AC. Comparison of microbial load in immersion chilling water and poultry carcasses after 8, 16 and 24 working hours. Ciência Rural 2010;40:1603-1609.

Ghafir Y, China B, Dierick K, De Zutter L, Daube G. Hygiene indicator microorganisms for selected pathogens on beef, pork, and poultry meats in Belgium. Journal of Food Protection 2008;71(1):35-45.

Goksoy EO, Kirkan S, Kok F. Microbiological quality of broiler carcasses during processing in two slaughterhouses in Turkey. Poultry Science 2004;83(8):1427-1432.

Heggum C, Vallejos JJG, Njie OB, Adegboye AO. Application of the moving window approach in the verification of the performance of food safety management systems. Food Control 2015;58:17-22.

Hutchison ML, Walters LD, Mead GC, Howell M, Allen VM. An assessment of sampling methods and microbiological hygiene indicators for process verification in poultry slaughterhouses. Journal of Food Protection 2006;69(1):145-153
Sala RMP, Balabarca VC, Etoundi JM, Odame-Darkwah J, Oppong-Otoo J, Hinson DCT, et al. Establishment of good hygiene practice-based microbiological criteria in food industries: Guidelines using an example for meat preparations. Food Control 2015;587-11.

Jimenez SM, Tiburzi MC, Salsi MS, Pirovani ME, Moguilevsky MA. The role of visible faecal material as a vehicle for generic Escherichia coli, coliform, and other enterobacteria contaminating poultry carcasses during slaughtering. Journal of Applied Microbiology 2003;95(3):451456 .

Matias BG, Pinto PS, Cossi MV, Nero LA. Salmonella spp. and hygiene indicator microorganisms in chicken carcasses obtained at different processing stages in two slaughterhouses. Foodborne Pathogens and Disease 2010;7(3):313-318.

Milios KT, Drosinos EH, Zoiopoulos PE. Food Safety Management System validation and verification in meat industry: Carcass sampling methods for microbiological hygiene criteria - A review. Food Control 2014;43(1):74-81.

Nogrady N, Kardos G, Bistyak A, Turcsanyi I, Meszaros J, Galantai Z, et al. Prevalence and characterization of Salmonella Infantis isolates originating from different points of the broiler chicken-human food chain in Hungary. International Journal of Food Microbiology 2008;127(1-2):162-167

Potter BD, Marcy JA, Owens CM, Slavik MF, Goodwin HL, Apple JK. Impact of performance-based sanitation systems on microbiological characteristics of poultry processing equipment and carcasses as compared with traditional sanitation systems. The Journal of Applied Poultry Research 2012;21(3):669-678.

Reij MW, Den Aantrekker ED. Recontamination as a source of pathogens in processed foods. International Journal of Food Microbiology 2004;91(1):1-11.

Rodrigues ACA, Pinto PSA, Vanetti MCD, Bevilacqua PD, Pinto MS, Nero LA. Análise e monitoramento de pontos críticos no abate de frangos utilizando indicadores microbiológicos. Ciência Rural 2008;38(7):19481953.

Scott VN, Powell M, Cabrera J, Carullo ME, Martinez I, Lohachoompol V. Development of microbiological criteria to assess the acceptability of a food lot - an example for milk powder. Food Control 2015;58(1):1216.

Stannard C. Development and use of microbiological criteria for foods. Food Science and Technology Today 1997;11(3):137-177.

Tirolli ICC, Costa CA. Ocorrência de Salmonella spp. em carcaças de frangos recém abatidos em feiras e mercados da cidade de Manaus-AM. Acta Amazonica 2006;36(2):205-208.

USDA/FSIS. Isolation and identification of salmonella from meat, poultry, pasteurized egg, and catfish products and carcass and environmental sponges. Athens: Laboratory Guidebook Notice Change; 2014. 19 p.

Vaidya VM, Paturkar AM, Waskar VS, Zende RJ, Rawool DB. Detection of indicator organisms on poultry carcass sites in an organized slaughterhouse. Journal of Muscle Foods 2005;16(4):289-297.

Zweifel C, Althaus D, Stephan R. Effects of slaughter operations on the microbiological contamination of broiler carcasses in three abattoirs. Food Control 2015;51(1):37-42. 
